九州大学学術情報リポジトリ

Kyushu University Institutional Repository

\title{
Environmental Impact Assessment of Orchard Soilds by the Heavy Metal Concentration in Yantai City of Shandong Province, China
}

Han, Jing-Long

School of Environment and material Engineering, Yantai University

Jin, Fu-Shun

School of Environment and material Engineering, Yantai University

Zhao, Ming

School of Environment and material Engineering, Yantai University

Egashira, Kazuhiko

Faculty of Agriculture, Kyushu University

https://doi.org/10.5109/9293

出版情報：九州大学大学院農学研究院紀要. 52 (1)，pp.123-128，2007-02-28. Faculty of Agriculture, Kyushu University

バージョン：

権利関係 : 


\title{
Environmental Impact Assessment of Orchard Soils by the Heavy Metal Concentration in Yantai City of Shandong Province, China
}

\author{
Jing-Long HAN ${ }^{1}$, Fu-Shun JIN $^{1}$, Ming ZHAO ${ }^{1}$ and Kazuhiko EGASHIRA* \\ Laboratory of Soil Science, Division of Soil Science and Plant Production, \\ Department of Plant Resources, Faculty of Agriculture, \\ Kyushu University, Fukuoka 812-8581, Japan \\ (Received October 26, 2006 and accepted December 1, 2006)
}

\begin{abstract}
With aims of improvement of soil fertility management, achievement of safe crop production and development of sustainable agriculture in the orchard, surface and subsurface soil samples were collected at nine different orchards in the two regions of Dashitong and Jiajiazhongchun in Yantai City, Shandong Province, China. Concentrations of selected heavy metals in soil were determined to carry out the environmental impact assessment of the orchard soils.

The soils in Dashitong where 50-year-old trees are growing showed a clear tendency of $\mathrm{Cu}$ accumulation, and the simple pollution index was 0.45 for $\mathrm{Cu}$ as a whole. The $\mathrm{Cd}$ concentration exceeded the soil environmental standard in all soils to show the simple pollution index of 1.73. The overall pollution index of the soils was 1.27 , which indicated the pollution status of "slightly polluted" in the orchard soils.

In order to reduce the heavy metal concentration of the orchard soils, the mixed cropping with crops such as soybean is desirable to make absorption of heavy metals by the crops as much as possible, in addition to application of organic fertilizer of the environmental preservation type having no or safe-level heavy metal.
\end{abstract}

\section{INTRODUCTION}

The type and amount of chemical substances released to arable land is rapidly increasing with development of industrial technology. In harmony with it, pollution of soil by heavy metals is becoming conspicuous. In every year $\mathrm{Hg}$ of 15,000 ton, $\mathrm{Cu}$ of $3,400,000$ ton, $\mathrm{Pb}$ of 5,000,000ton and $\mathrm{Ni}$ of $1,000,000$ ton are discharged in the world. The arable land area polluted by heavy metals reaches 20,000,000 ha in China, which causes the economic loss of 20 billion yuan. Recently, development of industry and enlargement of the area irrigated by polluted water bring about serious environmental pollution by heavy metals in Shandong Province of China. It makes a limiting factor of industrial development. Therefore, prevention of soil from heavy metal pollution and remediation of polluted soil are urgent tasks to be solved.

Yantai City is located in the coastal area of Shandong Province where innovation was first performed in China. As a result, urbanization of the city advances rapidly and the heavy metal pollution of soil around the city becomes severe more and more with advancement of the urbanization. Due to impossibility of the complete recovery of the polluted soil by the present technology and necessity of enormous cost, materials and manpower for remediation of the polluted soil, our research policy is to control soil pollution mainly by practicing scientifically the fertility management of cultivated soil.

${ }^{1}$ School of Environment and Material Engineering, Yantai University, Yantai City, Shandong Province, China; E-mail address of the top author: hanjinglong8868@yahoo.co.jp

* Corresponding author (E-mail: kegashi@agr.kyushu-u.ac.jp)
Orchard is widely distributed around Yantai City. In recent years, fruit farms of a certain size are being developed, and keeping quality of fruit trees becomes important. In the present study, chemical properties of the orchard soils were clarified for the proper fertility management of the orchard, and the heavy metal concentrations of the orchard soils were measured, followed by the environmental impact assessment, with aims of maintenance of the quality of fruits and sustainable development of fruit production.

\section{MATERIALS AND METHODS}

\section{Soil samples}

Eighteen surface and subsurface soil samples were collected at 9 different orchards in the two regions of Dashitong (D1 to D3) and Jiajiazhongchun (J1 to J6) in Yantai City, Shandong Province of China. Brief description of the soil samples is given in Table 1. The age of trees in the orchard was 50 years in Dashitong and 30 and 15 years in Jiajiazhongchun. Sampling was done in April 2006, and $1 \mathrm{~kg}$ of soil sample was taken from each depth at the sampling locations. Collected soil samples were air-dried at room temperature followed by the chemical and heavy metal analyses.

\section{Chemical analyses}

Chemical properties of soils were mainly analyzed according to the soil standard methods for analysis (Committee of Soil Standard Methods for Analyses and Measurements (ed), 1986). The $\mathrm{pH}$ was measured in the suspension having a soil:water ratio of 1:2.5. The organic carbon content was determined by the Tyurin method and multiplied by the coefficient of 1.724 to give the organic matter content. The total nitrogen content 
Table 1. Brief description of the soils used in the study

\begin{tabular}{|c|c|c|c|}
\hline Region & $\begin{array}{c}\text { Sample } \\
\text { No }\end{array}$ & $\begin{array}{c}\text { Tree age } \\
\text { (year) }\end{array}$ & $\begin{array}{c}\text { Depth } \\
(\mathrm{cm})\end{array}$ \\
\hline \multirow{3}{*}{ Dashitong } & D1 & \multirow{3}{*}{50} & $\begin{array}{r}0-20 \\
20-40 \\
\end{array}$ \\
\hline & D2 & & $\begin{array}{r}0-20 \\
20-40 \\
\end{array}$ \\
\hline & D3 & & $\begin{array}{r}0-20 \\
20-40 \\
\end{array}$ \\
\hline \multirow{6}{*}{ Jiajiazhongchun } & J1 & \multirow{3}{*}{30} & $\begin{array}{r}0-20 \\
20-40 \\
\end{array}$ \\
\hline & J2 & & $\begin{array}{r}0-20 \\
20-40 \\
\end{array}$ \\
\hline & J3 & & $\begin{array}{r}0-20 \\
20-40 \\
\end{array}$ \\
\hline & $\mathrm{J} 4$ & \multirow{3}{*}{15} & $\begin{array}{r}0-20 \\
20-40\end{array}$ \\
\hline & J5 & & $\begin{array}{r}0-20 \\
20-40 \\
\end{array}$ \\
\hline & J6 & & $\begin{array}{r}0-20 \\
20-40 \\
\end{array}$ \\
\hline
\end{tabular}

was determined by the Kjeldahl method. The total phosphorus content was determined by the ascorbic acid method after decomposition with perchloric acid. The soil was digested by the $\mathrm{HF}-\mathrm{HNO}_{3}-\mathrm{HClO}_{4}$ acid treatment and analyzed for total potassium by an atomic absorption spectrophotometer.

\section{Determination of heavy metal concentration}

Digestion with the $\mathrm{HF}-\mathrm{HNO}_{3}-\mathrm{HClO}_{4}$ acid treatment was used to determine total concentrations of heavy metals (Committee of Soil Standard Methods for Analyses and Measurements (ed), 1986). One g of the pulverized air-dry sample was weighed accurately into a teflon beaker, and $5 \mathrm{~mL}$ of the conc. $\mathrm{HClO}_{4}$ solution and $5 \mathrm{~mL}$ of the conc. $\mathrm{HNO}_{3}$ solution were added to the sample. The beaker was covered and heated for $3 \mathrm{~h}$ on a hot plate, and then heated without cover until dryness. After cooling and gradual addition of $5 \mathrm{~mL}$ of the conc. $\mathrm{HClO}_{4}$ solution and $10 \mathrm{~mL}$ of the $\mathrm{HF}$ solution in this sequence, the beaker was heated for 15 min. Heating was stopped and then continued until dryness after addition of another $10 \mathrm{~mL}$ of the $\mathrm{HF}$ solution. The beaker was cooled, added with $5 \mathrm{~mL}$ of $6 \mathrm{M} \mathrm{HCl}$ and $1 \mathrm{~mL}$ of the conc. $\mathrm{HNO}_{3}$ solution, and heated with cover for 1 h. The beaker was filled-up to two-thirds of the volume with water, covered, and heated to boiling for $2 \mathrm{~h}$. The solution was transferred into a 50-mL volumetric flask and made up to the mark with water after cooling. The solution was quickly transferred into a plastic bottle and analyzed for $\mathrm{Cd}, \mathrm{Cr}, \mathrm{Cu}, \mathrm{Pb}$ and $\mathrm{Zn}$ by an atomic absorption spectrophotometer.

Ten $g$ of the air-dry sample was weighed accurately into a 100-mL wide-mouth bottle, added with $50.0 \mathrm{~mL}$ of $0.1 \mathrm{M} \mathrm{HCl}$, shaken for $1 \mathrm{~h}$ with keeping temperature at $30{ }^{\circ} \mathrm{C}$, and centrifuged. The heavy metal concentration in the supernatant was measured by an atomic absorption spectrophotometer to determine the concentration of soluble heavy metals in soil.

\section{Calculation equation of simple and overall pollu- tion indexes}

The simple pollution index by a heavy metal was calculated by the equation of (measured heavy metal concentration/soil environmental standard). The overall pollution index by heavy metals was calculated by the equation of $(\sqrt{ }$ (square of the average of the simple pollution indexes + square of the maximum simple pollution index) $/ \sqrt{2}$ ).

\section{RESULTS}

\section{Fruit cultivation}

The examined orchards were all an apple orchard. The planting density was 80 100 trees per $667 \mathrm{~m}^{2}$. Compound fertilizer and raw poultry manure were applied to apple trees. The application rate of compound fertilizer (N-P-K: 14-6-10) was 250 300 kg per $667 \mathrm{~m}^{2}$.

\section{Chemical properties of soils in the orchard}

Chemical properties of soils in the orchard are shown in Table 2. The $\mathrm{pH}$ of the surface soil $(0-20 \mathrm{~cm}$ deep) was 6.3 to 7.5 and was in the almost neutral range. In contrast, the $\mathrm{pH}$ of the subsurface soil (20-40 cm deep) varied considerably from 4.8 to 7.6 and was in the strongly acid to neutral range. It suggests that reclamation of soil $\mathrm{pH}$ is limited to the surface soil depending on the locations.

The organic matter content ranged from 5.9 to $43.9 \mathrm{~g} \mathrm{~kg}^{-1}$ in the surface soil and from 3.2 to $39.3 \mathrm{~g} \mathrm{~kg}^{-1}$ in the subsurface soil. The organic matter contents of D1, D3, J2 and J3 exceeded $41.0 \mathrm{~g} \mathrm{~kg}^{-1}$ in the surface soil and $30.8 \mathrm{~g} \mathrm{~kg}^{-1}$ in the subsurface soil. The relatively heavy application of poultry manure is supposed to the orchard of those locations.

The total $\mathrm{N}$ content of the surface soil was highest for D1 with the value of $1.11 \mathrm{~g} \mathrm{~kg}^{-1}$; it was lower than $0.7 \mathrm{~g} \mathrm{~kg}^{-1}$ for the other locations. The total $\mathrm{P}_{2} \mathrm{O}_{5}$ content exceeded $1.0 \mathrm{~g} \mathrm{~kg}^{-1}$ only for D1 and $\mathrm{J} 1$ in both surface and subsurface soils; the highest value was $2.26 \mathrm{~g} \mathrm{~kg}^{-1}$ of the surface soil of $\mathrm{J} 1$. The total $\mathrm{K}_{2} \mathrm{O}$ content ranged from 6.4 to $18.6 \mathrm{~g} \mathrm{~kg}^{-1}$ in the surface soil and from 8.3 to $27.6 \mathrm{~g} \mathrm{~kg}^{-1}$ in the subsurface soil.

\section{Total heavy metal concentrations of soils in the orchard}

Total heavy metal concentrations of soils in the orchard are shown in Table 3. The total Cu concentration varied from 26.80 to $175.59 \mathrm{mg} \mathrm{kg}^{-1}$ in the surface soil and from 11.07 to $40.94 \mathrm{mg} \mathrm{kg}^{-1}$ in the subsurface soil, and the total $\mathrm{Cu}$ concentration in the surface soil was higher by more than double for the orchards in Dashitong than for the orchards in Jiajiazhongchun. The total Zn concentration ranged from 15.63 to $29.50 \mathrm{mg}$ $\mathrm{kg}^{-1}$ in the surface soil and from 12.60 to $26.13 \mathrm{mg} \mathrm{kg}^{-1}$ in the subsurface soil, and the total Cr concentration was in a range between 23.16 and $41.53 \mathrm{mg} \mathrm{kg}^{-1}$ in the surface soil and between 21.43 and $32.64 \mathrm{mg} \mathrm{kg}^{-1}$ in the subsurface soil. The total $\mathrm{Pb}$ concentration ranged from 
Table 2. Chemical properties of soils in the orchard

\begin{tabular}{|c|c|c|c|c|c|c|c|}
\hline \multirow[t]{2}{*}{ Region } & \multirow[t]{2}{*}{ Sample No } & \multirow{2}{*}{$\begin{array}{c}\text { Depth } \\
(\mathrm{cm})\end{array}$} & \multirow[t]{2}{*}{$\mathrm{pH}$} & $\begin{array}{l}\text { Organic } \\
\text { matter }\end{array}$ & $\begin{array}{c}\text { Total } \\
\mathrm{N}\end{array}$ & $\begin{array}{l}\text { Total } \\
\mathrm{P}_{2} \mathrm{O}_{5}\end{array}$ & $\begin{array}{c}\text { Total } \\
\mathrm{K}_{2} \mathrm{O}\end{array}$ \\
\hline & & & & \multicolumn{4}{|c|}{$\left(\mathrm{g} \mathrm{kg}^{-1}\right)$} \\
\hline \multirow{6}{*}{ Dashitong } & \multirow{2}{*}{ D1 } & $0-20$ & 7.5 & 43.9 & 1.11 & 1.24 & 15.8 \\
\hline & & $20-40$ & 7.6 & 39.3 & 0.52 & 1.10 & 10.5 \\
\hline & \multirow{2}{*}{ D2 } & $0-20$ & 7.0 & 14.8 & 0.38 & 0.85 & 16.1 \\
\hline & & $20-40$ & 5.2 & 8.6 & 0.29 & 0.55 & 9.9 \\
\hline & \multirow{2}{*}{ D3 } & $0-20$ & 6.9 & 42.0 & 0.68 & 0.98 & 18.6 \\
\hline & & $20-40$ & 4.8 & 30.8 & 0.46 & 0.72 & 14.8 \\
\hline \multirow{12}{*}{ Jiajiazhongchun } & \multirow{2}{*}{ J1 } & $0-20$ & 7.0 & 14.5 & 0.25 & 2.26 & 9.1 \\
\hline & & $20-40$ & 5.3 & 13.8 & 0.25 & 1.24 & 25.3 \\
\hline & \multirow{2}{*}{ J2 } & $0-20$ & 6.8 & 42.8 & 0.63 & 0.55 & 15.4 \\
\hline & & $20-40$ & 5.3 & 37.5 & 0.37 & 0.38 & 27.6 \\
\hline & \multirow{2}{*}{ J3 } & $0-20$ & 6.4 & 41.0 & 0.43 & 0.45 & 15.9 \\
\hline & & $20-40$ & 6.9 & 32.3 & 0.31 & 0.39 & 12.6 \\
\hline & \multirow{2}{*}{ J4 } & $0-20$ & 6.3 & 5.9 & 0.19 & 0.79 & 9.7 \\
\hline & & $20-40$ & 5.8 & 4.5 & 0.11 & 0.78 & 8.6 \\
\hline & \multirow{2}{*}{ J5 } & $0-20$ & 6.3 & 22.2 & 0.24 & 0.77 & 7.9 \\
\hline & & $20-40$ & 6.5 & 11.0 & 0.24 & 0.75 & 11.6 \\
\hline & \multirow{2}{*}{ J6 } & $0-20$ & 6.7 & 15.5 & 0.13 & 0.74 & 6.4 \\
\hline & & $20-40$ & 6.2 & 3.2 & 0.11 & 0.71 & 8.3 \\
\hline
\end{tabular}

Table 3. Total heavy metal concentrations of soils in the orchard $\left(\mathrm{mg} \mathrm{kg}^{-1}\right)$

\begin{tabular}{|c|c|c|c|c|c|c|}
\hline Heavy metal & & $\mathrm{Cu}$ & Zn & $\mathrm{Cr}$ & $\mathrm{Pb}$ & $\mathrm{Cd}$ \\
\hline Depth(cm) & & $0-20$ & $0-20$ & $0-20$ & $0-20$ & $0-20$ \\
\hline \multirow{3}{*}{ Dashitong } & D1 & 175.59 & 29.50 & 36.86 & 12.28 & 0.50 \\
\hline & D2 & 150.63 & 15.63 & 32.59 & 5.52 & 0.64 \\
\hline & D3 & 144.08 & 25.69 & 32.47 & 5.17 & 0.48 \\
\hline \multirow{6}{*}{ Jiajiazhongchun } & J1 & 43.45 & 20.47 & 29.17 & 11.01 & 0.62 \\
\hline & $\mathrm{J} 2$ & 90.24 & 24.94 & 39.65 & 12.41 & 0.36 \\
\hline & J3 & 35.31 & 16.41 & 36.58 & 6.66 & 0.47 \\
\hline & $\mathrm{J} 4$ & 69.91 & 19.31 & 27.05 & 7.15 & 0.57 \\
\hline & J5 & 69.80 & 24.38 & 41.53 & 8.66 & 0.46 \\
\hline & $\mathrm{J} 6$ & 26.80 & 26.31 & 23.16 & 6.05 & 0.58 \\
\hline Average \pm SD & & $89.53 \pm 18.21$ & $22.52 \pm 7.67$ & $33.23 \pm 2.01$ & $8.32 \pm 0.96$ & $0.52 \pm 0.03$ \\
\hline Heavy metal & & $\mathrm{Cu}$ & Zn & $\mathrm{Cr}$ & $\mathrm{Pb}$ & $\mathrm{Cd}$ \\
\hline Depth $(\mathrm{cm})$ & & $20-40$ & $20-40$ & $20-40$ & $20-40$ & $20-40$ \\
\hline \multirow{3}{*}{ Dashitong } & D1 & 11.07 & 23.12 & 24.67 & 7.07 & 0.97 \\
\hline & D2 & 23.17 & 26.13 & 23.36 & 5.51 & 0.47 \\
\hline & D3 & 40.94 & 22.59 & 25.51 & 5.32 & 0.60 \\
\hline \multirow{6}{*}{ Jiajiazhongchun } & J1 & 12.04 & 23.75 & 31.04 & 7.66 & 0.48 \\
\hline & $\mathrm{J} 2$ & 25.61 & 12.60 & 28.93 & 10.42 & 0.58 \\
\hline & J3 & 21.10 & 12.79 & 32.64 & 6.00 & 0.59 \\
\hline & J4 & 34.04 & 18.76 & 26.35 & 7.65 & 0.52 \\
\hline & J5 & 32.10 & 18.70 & 21.43 & 5.78 & 0.35 \\
\hline & J6 & 39.89 & 19.18 & 30.41 & 7.37 & 0.77 \\
\hline Average \pm SD & & $26.66 \pm 3.66$ & $19.74 \pm 1.57$ & $27.15 \pm 1.27$ & $6.98 \pm 0.53$ & $0.59 \pm 0.06$ \\
\hline
\end{tabular}

5.17 to $12.41 \mathrm{mg} \mathrm{kg}^{-1}$ in the surface soil and from 5.32 to $10.42 \mathrm{mg} \mathrm{kg}^{-1}$ in the subsurface soil, and the total $\mathrm{Cd}$ concentration was in a range of 0.36 to $0.64 \mathrm{mg} \mathrm{kg}^{-1}$ in the surface soil and of 0.35 to $0.97 \mathrm{mg} \mathrm{kg}^{-1}$ in the subsurface soil. In the total concentrations of $\mathrm{Zn}, \mathrm{Cr}, \mathrm{Pb}$ and $\mathrm{Cd}$, there was observed not much difference between orchards in the two regions and between soil depths in an orchard.

\section{Soluble heavy metal concentrations of soils in the} orchard

Soluble heavy metal concentrations of soils in the orchard are shown in Table 4. The soluble $\mathrm{Cu}$ concentration varied from 1.26 to $22.80 \mathrm{mg} \mathrm{kg}^{-1}$ in the surface soil and from 0.63 to $6.61 \mathrm{mg} \mathrm{kg}^{-1}$ in the subsurface soil. The soluble $\mathrm{Cu}$ concentration was mostly higher for the surface soil than for the subsurface soil in each orchard, and it was ascribed to accumulation of total $\mathrm{Cu}$ in the 
Table 4. Soluble heavy metal concentrations of soils in the orchard $\left(\mathrm{mg} \mathrm{kg}^{-1}\right)$

\begin{tabular}{|c|c|c|c|c|c|c|}
\hline Heavy metal & & $\mathrm{Cu}$ & $\mathrm{Zn}$ & $\mathrm{Cr}$ & $\mathrm{Pb}$ & $\mathrm{Cd}$ \\
\hline $\operatorname{Depth}(\mathrm{cm})$ & & $0-20$ & $0-20$ & $0-20$ & $0-20$ & $0-20$ \\
\hline \multirow{3}{*}{ Dashitong } & D1 & $11.87(6.8)^{1)}$ & $3.13(10.6)$ & $0.58(1.6)$ & $0.89(7.3)$ & $0.14(27.7)$ \\
\hline & D2 & $11.72(7.8)$ & $2.09(5.9)$ & $0.11(0.3)$ & $1.13(20.4)$ & $0.06(8.9)$ \\
\hline & D3 & $7.48(5.2)$ & $1.51(5.9)$ & $0.69(2.1)$ & $1.22(23.6)$ & $0.10(20.3)$ \\
\hline \multirow{6}{*}{ Jiajiazhongchun } & J1 & $2.95(6.8)$ & $0.57(2.8)$ & $0.58(2.0)$ & $1.09(9.9)$ & $0.08(12.2)$ \\
\hline & J2 & $9.30(10.3)$ & $1.61(6.5)$ & $0.56(1.4)$ & $1.13(9.1)$ & $0.07(19.9)$ \\
\hline & J3 & $7.95(22.5)$ & $0.60(3.7)$ & $0.71(1.9)$ & $1.19(17.9)$ & 0.07 (14.8) \\
\hline & J4 & $16.61(23.8)$ & $0.66(3.5)$ & $0.53(2.0)$ & $1.17(16.4)$ & 0.08 (13.8) \\
\hline & J5 & $22.80(32.7)$ & $4.10(16.8)$ & $0.06(0.2)$ & $1.27(14.7)$ & $0.08(16.9)$ \\
\hline & J6 & $1.26(4.7)$ & $0.42(1.6)$ & $0.07(0.3)$ & $1.10(18.1)$ & $0.04(6.8)$ \\
\hline Average \pm SD & & $10.22 \pm 2.21$ & $1.64 \pm 0.43$ & $0.44 \pm 0.09$ & $1.13 \pm 0.04$ & $0.08 \pm 0.009$ \\
\hline Heavy metal & & $\mathrm{Cu}$ & $\mathrm{Zn}$ & $\mathrm{Cr}$ & $\mathrm{Pb}$ & $\mathrm{Cd}$ \\
\hline $\operatorname{Depth}(\mathrm{cm})$ & & $20-40$ & $20-40$ & $20-40$ & $20-40$ & $20-40$ \\
\hline \multirow{3}{*}{ Dashitong } & D1 & $1.09(9.9)$ & $0.80(3.5)$ & $0.43(1.7)$ & $0.90(12.7)$ & $0.03(2.7)$ \\
\hline & $\mathrm{D} 2$ & $0.97(4.2)$ & $0.38(1.5)$ & $0.55(2.4)$ & $0.80(14.6)$ & $0.08(16.5)$ \\
\hline & D3 & $1.78(4.4)$ & $0.63(2.8)$ & $0.67(2.6)$ & $1.07(20.0)$ & $0.05(8.0)$ \\
\hline \multirow{6}{*}{ Jiajiazhongchun } & J1 & $0.63(5.2)$ & $0.46(2.0)$ & $0.46(1.5)$ & $1.15(15.0)$ & $0.06(12.7)$ \\
\hline & J2 & $2.43(9.5)$ & $0.75(6.0)$ & $0.32(1.1)$ & $1.18(11.3)$ & $0.05(9.3)$ \\
\hline & J3 & $1.29(6.1)$ & $0.23(1.9)$ & $0.64(2.0)$ & $1.16(19.4)$ & $0.02(2.9)$ \\
\hline & J4 & $6.61(19.4)$ & $0.64(3.4)$ & $0.51(1.9)$ & $1.34(17.5)$ & $0.09(17.4)$ \\
\hline & $\mathrm{J} 5$ & $1.54(4.8)$ & $0.72(3.9)$ & $0.23(1.1)$ & $1.19(20.6)$ & $0.06(16.9)$ \\
\hline & J6 & $1.98(5.0)$ & $1.03(5.4)$ & $0.52(1.7)$ & $1.44(19.5)$ & $0.04(5.3)$ \\
\hline Average \pm SD & & $2.04 \pm 0.60$ & $0.63 \pm 0.08$ & $0.48 \pm 0.05$ & $1.14 \pm 0.06$ & $0.05 \pm 0.008$ \\
\hline
\end{tabular}

1) The ratio to the total concentration (\%).

surface soil. The soluble $\mathrm{Zn}$ concentration ranged from 0.42 to $4.10 \mathrm{mg} \mathrm{kg}^{-1}$ in the surface soil and from 0.23 to $1.03 \mathrm{mg} \mathrm{kg}^{-1}$ in the subsurface soil, and the soluble $\mathrm{Cr}$ concentration was in a range between 0.06 to $0.71 \mathrm{mg}$ $\mathrm{kg}^{-1}$ in the surface soil and from 0.23 to $0.67 \mathrm{mg} \mathrm{kg}^{-1}$ in the subsurface soil. The soluble $\mathrm{Pb}$ concentration ranged from 0.89 to $1.27 \mathrm{mg} \mathrm{kg}^{-1}$ in the surface soil and from 0.80 to $1.44 \mathrm{mg} \mathrm{kg}^{-1}$ in the subsurface soil, and the soluble $\mathrm{Cd}$ concentration was in a range of 0.04 to $0.14 \mathrm{mg} \mathrm{kg}^{-1}$ in the surface soil and of 0.02 to $0.09 \mathrm{mg} \mathrm{kg}^{-1}$ in the subsurface soil. The noticeable differences in soil depth and between orchards could not be recognized to the soluble concentrations of $\mathrm{Zn}, \mathrm{Cr}, \mathrm{Pb}$ and $\mathrm{Cd}$.

The ratio of the soluble to total concentrations was generally higher for the surface soil than for the subsurface soil in $\mathrm{Cu}, \mathrm{Zn}$ and $\mathrm{Cd}$, while tended to be lower for the surface soil than for the subsurface soil in Cr and $\mathrm{Pb}$.

\section{DISCUSSION}

T-test was done to analyze significance in the difference of total heavy metal concentrations between surface and subsurface soils. The results are shown in Table 5. A significant difference at the 10\% level was recognized to the total concentration of $\mathrm{Cu}$ between surface and subsurface soils, and the total $\mathrm{Cu}$ concentration was higher for the surface soil than for the subsurface soil. It points out accumulation of $\mathrm{Cu}$ in the surface layer of the orchards soils. This can be explained by application of various fertilizers contaminated with $\mathrm{Cu}$ and long-term use of the pesticide containing $\mathrm{Cu}$ as an essential component. The surface soil was also significantly (at the 10\% level) higher on the total Cr concentration than was the subsurface soil, although apparently not much difference was observed between surface and subsurface soils (Table 3). As causes of Cr accumulation in the surface soil, application of various fertilizers and/or long-term use of pesticides, both contaminated with Cr, are considered. The significant difference between surface and subsurface soils was not observed in the total concentrations of $\mathrm{Zn}, \mathrm{Pb}$ and $\mathrm{Cd}$.

F-test was carried out to analyze the effect of the age of trees on the total heavy metal concentration in the surface soil. The significant difference in the total heavy metal concentration between tree ages was recognized only to $\mathrm{Cu}$, as the analytical result is shown in Table 6. Then, the Duncan's multiple range test was

Table 5. T-test on significance in the difference of total heavy metal concentrations between surface and subsurface soils

\begin{tabular}{lccc}
\hline Heavy metal & $\mathrm{t}$ & $\mathrm{t}_{0.10,16}$ & Significant level \\
\hline $\mathrm{Cu}$ & 1.93 & 1.75 & $*$ \\
$\mathrm{Zn}$ & 0.41 & 1.75 & $(\mathrm{o})$ \\
$\mathrm{Cr}$ & 2.56 & 1.75 & $*$ \\
$\mathrm{~Pb}$ & 1.21 & 1.75 & $(\mathrm{o})$ \\
$\mathrm{Cd}$ & 1.03 & 1.75 & $(\mathrm{o})$ \\
\hline
\end{tabular}

*: significance at the $10 \%$ level.

(o): no significance. 
Table 6. The result of F-test done to the total $\mathrm{Cu}$ concentration in the surface soil between different tree ages

\begin{tabular}{|c|c|c|c|c|c|c|}
\hline Factor & $\mathrm{DF}$ & SS & MS & $\mathrm{F}$ & $\mathrm{F}_{0.05}$ & Significant level \\
\hline Between sets & 2 & 264.14 & 132.07 & 0.16 & 6.94 & \\
\hline During treatments & 2 & 20340.81 & 10170.41 & 12.4 & & $*$ \\
\hline Error & 4 & 3181.76 & 820.44 & & & \\
\hline Total variation & 8 & 23786.71 & & & & \\
\hline
\end{tabular}

*: significance at the $5 \%$ level.

carried out to analyze variation of the total $\mathrm{Cu}$ concentration with the three different tree ages. The result is shown in Table 7 . There was observed no significant difference between tree ages of 30 and 15 years, but the significant difference at the $5 \%$ level was recognized between tree age of 50 years and tree ages of 15 and 30 years. The difference in the tree ages has a possibility of difference due to the regions. However, this possibility is denied by the fact that the significant difference in the total $\mathrm{Cu}$ concentration between tree ages was not noticed in the subsurface soil. Accumulation of $\mathrm{Cu}$ in the surface soil of orchard gradually progresses and attains a significant level after cultivation of around 50 years due to improper fertility management or long-term application of chemical fertilizers and agricultural chemicals contaminated with or containing $\mathrm{Cu}$.

The orchard soils were evaluated in reference to the heavy metal concentration for effective field management and safe production of fruit products. The total concentration in the surface soil (Table 3) was compared with its soil environmental standard (Table 8) in different heavy metals. Total concentrations of $\mathrm{Cu}$, $\mathrm{Zn}$, Cr and $\mathrm{Pb}$ were within their soil environmental standards in the second standard, and the orchard soils were judged to be not polluted by those heavy metals. However, the averaged total $\mathrm{Cu}$ concentration of the Dashitong region was equal to $78 \%$ of the soil environmental standard, and the field management for pollution control is necessary to be performed. The total Cd concentration exceeded the soil environmental standard in all soils examined, and it was stated that pollution of the orchard soils by Cd was clearly detected. However, the total $\mathrm{Cd}$ concentration was not significantly different between surface and subsurface soils and between tree ages. Therefore, unidentified sources or reasons for its pollution may be considered, in addition to contamination through application of chemical fertilizers and agricultural chemicals.

The simple and overall pollution indexes by the total heavy metal concentrations were evaluated for the environmental impact assessment of the soils in the orchard. The simple pollution index is given in Table 8 . The simple pollution index was 0.45 for $\mathrm{Cu}$ as a whole. It was 1.73 for Cd and exceeded 1.00. The overall pollution index for the orchard soils examined was calculated as 1.27 , and they were designated as the pollution level of " 3 " or "slightly polluted" according to the classification of the soil pollution level based on the overall pollution index (Table 9). Contribution of $\mathrm{Cd}$ is great to the overall pollution index of 1.27. The crop starts to be suffered from soil pollution under the pollution status of "slightly polluted".

Based on the above discussion, it is mentioned that status of soil pollution is more worsened without proper
Table 7. Duncan's multiple range test to the total $\mathrm{Cu}$ concentration in the surface soil of different tree ages

\begin{tabular}{ccc}
\hline Tree age (year) & Average $\left(\mathrm{mg} \mathrm{kg}^{-1}\right)$ & Significant level (5\%) \\
\hline 50 & 156.76 & $\mathrm{a}$ \\
30 & 55.50 & $\mathrm{~b}$ \\
15 & 56.50 & $\mathrm{~b}$ \\
\hline
\end{tabular}

Different alphabets mean the difference at the $5 \%$ significant level.
Table 8. The simple pollution index of the surface soil by the total heavy metal concentration for different heavy metals

\begin{tabular}{cccc}
\hline $\begin{array}{c}\text { Heavy } \\
\text { metal }\end{array}$ & $\begin{array}{c}\text { Average } \pm \text { SD } \\
\left(\mathrm{mg} \mathrm{kg}^{-1}\right)\end{array}$ & $\begin{array}{c}\text { Soil environmental } \\
\text { standard } \\
\left(\mathrm{mg} \mathrm{kg}^{-1}\right)\end{array}$ & $\begin{array}{c}\text { Simple } \\
\text { pollution } \\
\text { index }\end{array}$ \\
\hline $\mathrm{Cu}$ & $89.53 \pm 18.21$ & 200 & 0.45 \\
$\mathrm{Zn}$ & $22.52 \pm 7.67$ & 250 & 0.09 \\
$\mathrm{Cr}$ & $33.23 \pm 2.01$ & 200 & 0.17 \\
$\mathrm{~Pb}$ & $8.32 \pm 0.96$ & 300 & 0.03 \\
$\mathrm{Cd}$ & $0.52 \pm 0.03$ & 0.30 & 1.73 \\
\hline
\end{tabular}

Table 9. Classification of the soil pollution level by heavy metals based on the overall pollution index

\begin{tabular}{cccc}
\hline Pollution level & Overall pollution index (P) & Status of pollution & Effect on soil and crops \\
\hline 1 & $\mathrm{P} \leqq 0.7$ & Hardly polluted & Nothing \\
2 & $0.7<\mathrm{P} \leqq 1.0$ & Near the pollution level & Scarcely affected \\
3 & $1.0<\mathrm{P} \leqq 2.0$ & Slightly polluted & Some crops start to be suffered from pollution \\
4 & $2.0<\mathrm{P} \leqq 3.0$ & Fairly polluted & Soil and crops are suffered from the middle degree of pollution \\
5 & $\mathrm{P}>3.0$ & Severely polluted & Soil and crops are suffered from severe pollution \\
\hline
\end{tabular}


and scientific field management practice. It will adversely affect quality of fruits and retard the sustainable fruit production. The total Cd concentration exceeded the soil environmental standard in all the soils examined, and the total $\mathrm{Cu}$ concentration approached to the environmental standard in the orchard of the Dashitong region where apple trees have been growing during 50 years. Therefore, it is necessary and important to take measures for prevention of soil pollution on the practice of field management in the orchard.

On the fertilizer application, the fertilizer use efficiency should be improved and simultaneously the amount of fertilizer applied should be reduced. In addition, it is desirable to use organic fertilizer of the environmental preservation type containing little heavy metals. Use of biological control agent is recommended, which exerts little pollution to the environment, when pesticide is applied. In the cultivation technique, the upland crop is grown between trees in the orchard to absorb $\mathrm{Cu}$ and $\mathrm{Cd}$ as much as possible for recovery of the soil from heavy metal pollution.

\section{CONCLUSIONS AND PROPOSAL}

In the soils of the apple orchard in Yantai City,
Shandong Province, China, the total Cd concentration exceeded the soil environmental standard and gave the highest simple pollution index among the five heavy metals of $\mathrm{Cu}, \mathrm{Zn}, \mathrm{Cr}, \mathrm{Pb}$ and $\mathrm{Cd}$ analyzed. The total $\mathrm{Cu}$ concentration showed the tendency to accumulate with increasing duration of the management as orchard. It is proposed that the upland crop is grown between trees in the orchard, by which alleviation of the soil pollution by $\mathrm{Cu}$ and $\mathrm{Cd}$ is intended due to absorption of heavy metals by the upland crop.

\section{ACKNOWLEDGEMENTS}

A part of the present research was financially supported by the Yantai University doctor fund and by the science and technology development plan fund of Yantai City. The authors express our sincere thanks to them for their financial support.

\section{REFERENCES}

Committee of Soil Standard Methods for Analyses and Measurements (ed) 1986 Soil Standard Methods for Analyses and Measurements. Hakuyusha, Tokyo (in Japanese) 